\title{
Mechanism of Effect of Alpha Adrenergic Stimulation with Norepinephrine on Renal Water Excretion
}

\author{
Robert W. Schrier and Tomas Berl with the technical assistance of \\ Judith A. Harbottle \\ From the Department of Medicine and the Cardiovascular Research Institute, \\ University of California at San Francisco, California 94122
}

\begin{abstract}
A B S T R A C T The present study was undertaken to investigate the mechanism whereby alpha adrenergic stimulation with intravenous norepinephrine results in a water diuresis. Renal perfusion pressure was kept constant in all experiments by adjustment of a suprarenal aortic clamp. In hydropenic anesthetized dogs the intravenous infusion of norepinephrine $(0.5 \mu \mathrm{g} / \mathrm{kg}$ per $\min$ ) was associated with a mean decrease in urinary osmolality from 616 to $126 \mathrm{mosmol} / \mathrm{kg} \quad(P<0.001)$ which increased to $532 \mathrm{mosmol} / \mathrm{kg}(P<0.001)$ after the infusion was discontinued. During the same period of time the mean free water clearance increased from -0.437 to $1.59(P<0.001)$ and then returned to $-0.314 \mathrm{ml} / \mathrm{min}(P<0.001)$ after cessation of the infusion. This diuretic effect occurred in both innervated and denervated kidneys and was not associated with an increase in glomerular filtration rate or solute excretion. Systemic arterial pressure increased from 121 to 142 $\mathrm{mm} \mathrm{Hg}$ during the norepinephrine infusion. Studies were also performed in hypophysectomized animals receiving a constant infusion of either $80 \mu \mathrm{g} / \mathrm{kg}$ per min or $20-40 \mu \mathrm{U} / \mathrm{kg}$ per min of vasopressin. In these animals, intravenous norepinephrine was not associated with changes in either urinary osmolality or free water clearance. The intrarenal administration of norepinephrine, in doses comparable with those reaching the kidneys during the intravenous studies, also resulted in no significant change in either urinary osmolality or free water clearance in hypophysectomized animals receiv-
\end{abstract}

A preliminary report of this work was presented at the 5th International Congress of Nephrology, 9 October 1972, in Mexico City.

Dr. Berl is a postdoctoral fellow supported by the $\mathrm{Na}$ tional Kidney Foundation. Dr. Schrier is an Established Investigator of the American Heart Association. Dr. Schrier's present address is the University of Colorado School of Medicine, Denver, Colo., 80220. (Address reprint requests to Dr. Schrier.)

Received for publication 1 August 1972 and in revised form 17 October 1972.

The Journal of Clinical Investigation Volume 52 February 1973 ing $20-30 \mu \mathrm{U} / \mathrm{kg}$ per $\mathrm{min}$ of vasopressin. These results thus indicate that the water diuresis associated with intravenous norepinephrine is mediated primarily by suppression of vasopressin release rather than by changes in renal hemodynamics, renal innervation, or an effect of norepinephrine on the water permeability of the tubular epithelium.

\section{INTRODUCTION}

The results of several previous investigations indicate that alpha adrenergic stimulation with the endogenous catecholamine, norepinephrine, is associated with an increase in the renal excretion of solute-free water (1-5). The mechanism for this diuretic effect, however, is not known. In earlier studies suppression of endogenous vasopressin release was proposed as the mechanism (1) and more recently an interrelationship between vasopressin $(\mathrm{ADH})^{1}$ and norepinephrine at the cellular level of the renal tubular epithelium has been suggested (3-5). The latter hypothesis has been considered attractive since the effect of vasopressin appears to be mediated by stimulating adenyl cyclase to catalyze the formation of $3^{\prime}, 5^{\prime}$-adenosine monophosphate (cyclic AMP) (6-8), a process which has been shown to be inhibited by alpha adrenergic stimulation in several tissues of the body (9-10). Support for this hypothesis is obtained from the observation that the effect of norepinephrine to produce a water diuresis may occur in the absence of increases in either solute excretion rate or glomerular filtration rate (1-3). Moreover, Strauch and Langdon (11) and Handler, Bensinger, and Orloff (12) have found that norepinephrine antago-

${ }^{1}$ Abbreviations used in this paper: $\mathrm{ADH}$, pitressin (antidiuretic hormone); $\mathrm{C}_{\mathrm{H}_{2} \mathrm{O}}$, free water clearance; FF, filtration fraction; GFR, glomerular filtration rate; NE, norepinephrine; RVR, renal vascular resistance; Uosm, urinary osmolality. 
nizes the in vitro effect of $\mathrm{ADH}$ on water transport by the toad bladder.

A consideration of the previous in vivo studies (1-5), however, does not allow a definitive conclusion that alpha adrenergic stimulation with norepinephrine exerts a direct effect on the water permeability of the renal tubular epithelium. In all of these previous experiments (1-5) the increase in renal arterial pressure which occurred during the intravenous administration of norepinephrine may have been responsible for the observed water diuresis $(13,14)$. In addition, alterations in systemic hemodynamics during the norepinephrine administration, such as changes in cardiac output, total peripheral resistance, and systemic arterial pressure, may have led to a suppression of vasopressin release. Somewhat against a suppression of vasopressin release accounting for the diuretic effect of norepinephrine is the finding that this effect has been observed during the infusion of exogenous vasopressin $(3,5)$. Submaximal doses of vasopressin were, however, used in these previous studies and no evidence was provided that maximal suppression of endogenous $\mathrm{ADH}$ was present at the time that the norepinephrine was infused $(3,5)$.

On the background of these in vivo studies (1-5), the present investigation was undertaken to examine the mechanisms of the diuretic effect of alpha adrenergic stimulation with norepinephrine and in particular to differentiate between a direct effect on the water permeability of the renal tubule, an effect mediated by alterations in renal arterial pressure or other renal hemodynamics, and an effect mediated by an extrarenal mechanism involving suppression of the release of $\mathrm{ADH}$. The results demonstrated that the diuretic effect of norepinephrine may occur in experiments in which the renal arterial pressure is maintained constant. This enhanced rate of water excretion was not associated with either an increase in glomerular filtration rate or solute excretion rate and was unaltered by renal denervation. However, neither the intravenous nor the intrarenal administration of norepinephrine was associated with a water diuresis in acutely hypophysectomized animals receiving an exogenous infusion of vasopressin. On the basis of these results, we therefore conclude that the major effect of alpha adrenergic stimulation with norepinephrine to enhance the renal excretion of solute-free water is mediated by an extrarenal mechanism involving the suppression of endogenous $\mathrm{ADH}$ rather than a direct effect on the water permeability of the tubular epithelium or an indirect effect related to an increase in renal arterial pressure, glomerular filtration rate, or solute excretion.

\section{METHODS}

33 experiments were performed in 22 mongrel dogs of either sex weighing $20-30 \mathrm{~kg}$. Food was withheld $18 \mathrm{~h}$ before study but water was allowed ad lib. On the morning of study the animals were anesthetized with intravenous pentobarbital $(30 \mathrm{mg} / \mathrm{kg})$, intubated, and ventilated with a Harvard respirator (Harvard Apparatus Co., Millis, Mass.). Light anesthesia was maintained throughout the experiment by the administration of pentobarbital. After induction of anesthesia all animals received $5 \mathrm{mg}$ of deoxycorticosterone acetate in oil intramuscularly. In 17 animals acute hypophysectomy was performed through a buccal approach, after which these animals received $0.8 \mathrm{mg}$ of dexamethasone both intramuscularly and intravenously. In all animals polyethylene catheters were placed in both ureters and renal veins through bilateral flank incisions using a retroperitoneal approach. Denervation of kidneys was performed by stripping and severing the renal nerves from the renal pedicle and then applying $95 \%$ alcohol to the renal pedicle. In most animals, an adjustable Blalock clamp was placed around the aorta above the origin of both renal arteries through the left flank incision. Catheters were placed in the aorta via the brachial and femoral artery for continuous measurement of arterial pressure above and below the aortic clamp, and into the vena cava from the femoral vein for continuous measurement of venous pressure. Both arterial and venous pressures were measured using Statham transducers (Statham Instruments, Inc., Oxnard, Calif.) and a direct writing Gilson recorder (Gilson Medical Electronics, Inc., Middleton, Wis.). A catheter was also placed into the right atrium via the jugular vein to inject indocyanine green dye for determination of cardiac output by the dye dilution method using methods and instruments as previously described (15). After completion of the surgery, an intravenous infusion of $2.5 \mathrm{~g} / 100 \mathrm{ml}$ glucose $(0.5 \mathrm{ml} / \mathrm{min})$ was started which contained sufficient inulin and paraaminohippuric acid (PAH) to maintain blood levels of these substances between 15 and 25 , and 1 and $3 \mathrm{mg} / 100 \mathrm{ml}$, respectively. Both of these infusions were continued throughout the experiments. The experiments were not started until at least 1-2 $\mathrm{h}$ after commencing the infusions and after stabilization of urine flow had occurred. Throughout the experiment urine was collected separately from each kidney at 10 to 20 -min intervals and arterial and renal venous blood samples were collected at the midpoint of alternate collections of urine. In two hypophysectomized animals the right kidney was lost because of surgical mishap during the insertion of the renal vein catheter so that urine collections were only made from the left kidney. Cardiac output measurements were made every third period during the experiment. The following four groups of experiments were performed.

Group I, intravenous norepinephrine in intact dogs. After three to five control periods 1-norepinephrine bitartrate $(0.5 \mu \mathrm{g} / \mathrm{kg}$ per $\mathrm{min})$ was infused intravenously and after a $30 \mathrm{~min}$ equilibration period three to five experimental periods were collected. The infusion of norepinephrine was then discontinued and after another $30 \mathrm{~min}$ equilibration period three to five postcontrol periods were collected. In all of the experiments, the renal perfusion pressure was maintained at the control level during the infusion of norepinephrine by adjustment of a suprarenal aortic clamp.

Group II, intravenous norepinephrine in acutely hypophyscctomized dogs receiving $80 \mu \mathrm{U} / \mathrm{kg}$ per min of vasopressin (Pitressin, 20 USP pressor $U / m l$ ). After completion of the surgery in these animals an infusion of $0.9 \%$ sodium chloride containing exogenous vasopressin $(80 \mu \mathrm{U} / \mathrm{kg}$ per min $)$ was started at $0.5 \mathrm{ml} / \mathrm{min}$. This dose was chosen after preliminary experiments demonstrated that this amount of exogenous vasopressin would produce a range of urinary os-

Norepinephrine and Renal Water Excretion 
TABLE I

Effect of Norepinephrine Infusion on Systemic and Renal

\begin{tabular}{|c|c|c|c|c|c|c|c|c|c|c|c|c|c|}
\hline & \multicolumn{3}{|c|}{ Cardiac output } & \multicolumn{3}{|c|}{$\begin{array}{c}\text { Systemic } \\
\text { arterial'pressure }\end{array}$} & \multicolumn{3}{|c|}{$\begin{array}{c}\text { Renal } \\
\text { perfusion pressure }\end{array}$} & \multicolumn{3}{|c|}{$\begin{array}{c}\text { Arterial } \\
\text { hematocrit volume }\end{array}$} & \multirow{2}{*}{$\frac{\text { GFR }}{\begin{array}{c}\text { Pre- } \\
\text { control }\end{array}}$} \\
\hline & $\begin{array}{l}\text { Pre- } \\
\text { control }\end{array}$ & $\mathrm{NE}$ & $\begin{array}{c}\text { Post- } \\
\text { controlł }\end{array}$ & $\begin{array}{l}\text { Pre- } \\
\text { control }\end{array}$ & $\mathrm{NE}$ & $\begin{array}{l}\text { Post- } \\
\text { control }\end{array}$ & $\begin{array}{l}\text { Pre. } \\
\text { control }\end{array}$ & $\mathrm{NE}$ & $\begin{array}{l}\text { Post- } \\
\text { control }\end{array}$ & $\begin{array}{l}\text { Pre- } \\
\text { control }\end{array}$ & $\mathrm{NE}$ & $\begin{array}{l}\text { Post- } \\
\text { control }\end{array}$ & \\
\hline & & & & \multicolumn{3}{|c|}{$m m ~ H g$} & \multicolumn{3}{|c|}{$m m \mathrm{Hg}$} & \multicolumn{3}{|c|}{$\%$} & $\mathrm{ml} / \min$ \\
\hline Mean & 3.8 . & 4.2 & 3.5 & 121 & 142 & 117 & 117 & 117 & 112 & 41.1 & 43.4 & 39.7 & 49.6 \\
\hline$\pm \mathrm{SE}$ & \pm 0.4 & \pm 0.7 & \pm 0.5 & \pm 7.8 & \pm 6.6 & \pm 8.4 & \pm 7.1 & \pm 5.6 & \pm 6.9 & \pm 1.4 & \pm 1.7 & \pm 1.7 & \pm 2.9 \\
\hline$P$ value & \multicolumn{2}{|c|}{ NS } & NS & \multicolumn{2}{|c|}{$<0.005$} & 0.005 & \multicolumn{2}{|c|}{ NS } & NS & \multicolumn{3}{|c|}{$<0.001$} & NS \\
\hline
\end{tabular}

* Precontrol, NE, and postcontrol represent periods before, during, and after norepinephrine infusion, respectively.

$\ddagger$ The results are the mean values from nine experiments; the values for renal hemodynamic and electrolyte excretion are expressed per kidney.

$\mathrm{NS}=$ not significant, $(P$ value $>0.05)$.

molalities in the hypophysectomized dogs which was comparable with the range of urinary osmolalities in the intact dogs (group I). The protocol was otherwise identical with that used in the group I experiments.

Group III, intravenous norepinephrine in acutely hypophysectomized dogs receiving $20-40 \mu U / \mathrm{kg}$ per min of vasopressin. These studies were performed to investigate whether an effect of intravenous norepinephrine to inhibit the action of vasopressin is demonstrable only at low doses of vasopressin. The protocol in these experiments was otherwise identical with that used in the group II experiments.

Group IV, infusion of norepinephrine $(0.05-0.06 \mu U / \mathrm{kg}$ per min) into the renal artery of hypophysectomized dogs receiving $20-30 \mu U / k g$ per $\min$ of vasopressin. These studies were performed to examine whether an amount of norepinephrine, which is equal to or greater than the amount of norepinephrine estimated to reach the kidney during the intravenous norepinephrine studies (group I), is associated with an effect on renal water excretion. With the exception that the norepinephrine was infused through a
23 gauge needle in the renal artery in $0.9 \%$ sodium chloride solution at $0.5 \mathrm{ml} / \mathrm{min}$, the protocol in these experiments was identical with that used in the group II experiments.

The analytical procedures and calculations used in the present experiments have been referred to elsewhere (16). The following abbreviations will be used: glomerular filtration rate (GFR), renal vascular resistance (RVR), filtration fraction $(\mathrm{FF})$, free water clearance $\left(\mathrm{C}_{\mathrm{H}_{2} \mathrm{O}}\right)$ and urinary osmolality $\left(\mathrm{U}_{\mathrm{osm}}\right)$. The student paired $t$ test was used for statistical analysis of results obtained in the same animal and the unpaired $t$ test was used for analysis of results in different groups of animals. A $P$ value $<0.05$ was considered significant.

\section{RESULTS}

Group I, effects of intravenous norepinephrine (NE) in hydropenic dogs (Fig. 1, Table I). The results in group I, as well as groups II-IV, were not significantly different in the innervated and denervated kidneys therefore the results of all the kidneys have been ana-
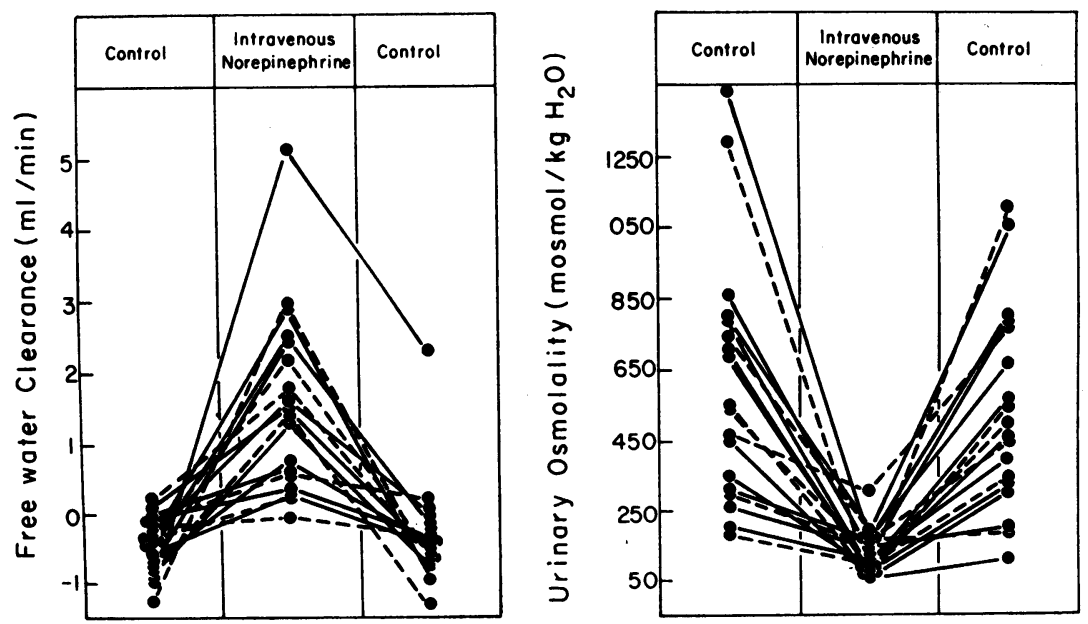

FIGURE 1 Effect of intravenous norepinephrine on free water clearance (left) and urinary osmolality (right) in the hydropenic dog. Each point represents the mean of three to five collection periods. Solid lines denote results in innervated kidneys and dotted lines in denervated kidneys. 
Hemodynamics and Electrolyte Excretion in Intact Dogs*

\begin{tabular}{|c|c|c|c|c|c|c|c|c|c|c|c|c|c|}
\hline \multicolumn{2}{|c|}{ GFR } & \multicolumn{3}{|c|}{ RVR } & \multicolumn{3}{|c|}{$\mathrm{FF}$} & \multicolumn{3}{|c|}{$\begin{array}{c}\text { Urinary } \\
\text { sodium excretion }\end{array}$} & \multicolumn{3}{|c|}{$\begin{array}{c}\text { Urinary } \\
\text { potassium excretion }\end{array}$} \\
\hline $\mathrm{NE}$ & $\begin{array}{l}\text { Post- } \\
\text { control }\end{array}$ & $\begin{array}{l}\text { Pre- } \\
\text { control }\end{array}$ & $\mathrm{NE}$ & $\begin{array}{l}\text { Post- } \\
\text { control }\end{array}$ & $\begin{array}{c}\text { Pre- } \\
\text { control }\end{array}$ & NE & $\begin{array}{c}\text { Post- } \\
\text { control }\end{array}$ & $\begin{array}{l}\text { Pre- } \\
\text { control }\end{array}$ & $\mathrm{NE}$ & $\begin{array}{l}\text { Post- } \\
\text { control }\end{array}$ & $\begin{array}{l}\text { Pre- } \\
\text { control }\end{array}$ & $\mathrm{NE}$ & $\begin{array}{l}\text { Post- } \\
\text { control }\end{array}$ \\
\hline \multicolumn{2}{|c|}{$\mathrm{ml} / \mathrm{min}$} & \multicolumn{3}{|c|}{$m m H g(m l / m i n)$} & & & & \multicolumn{3}{|c|}{$\mu e q / \min$} & \multicolumn{3}{|c|}{$\mu e q / \min$} \\
\hline $\begin{array}{r}50.3 \\
\pm 3.1\end{array}$ & $\begin{array}{r}53.5 \\
\pm 3.2\end{array}$ & $\begin{aligned} & 0.495 \\
\pm & 0.05\end{aligned}$ & $\begin{aligned} & 0.495 \\
\pm & 0.06\end{aligned}$ & $\begin{aligned} & 0.439 \\
\pm & 0.05\end{aligned}$ & $\begin{aligned} & 0.331 \\
\pm & 0.01\end{aligned}$ & $\begin{aligned} & 0.348 \\
\pm & 0.02\end{aligned}$ & $\begin{aligned} & 0.315 \\
\pm & 0.01\end{aligned}$ & $\begin{array}{l}22 \\
\pm 8.0\end{array}$ & $\begin{array}{c}11 \\
\pm 2.3\end{array}$ & $\begin{array}{l}33 \\
\pm 8.1\end{array}$ & $\begin{array}{l}26 \\
\pm 2.4\end{array}$ & $\begin{array}{c}28 \\
\pm 3.9\end{array}$ & $\begin{array}{l}36 \\
\pm 3.3\end{array}$ \\
\hline NS & & N & & $\mathrm{S}$ & & $S<0.0$ & & & $0<0$ & & & S & NS \\
\hline
\end{tabular}

lyzed together. The intravenous infusion of NE was associated with a diminution in $\mathrm{U}_{\mathrm{osm}}$ and an increase in $\mathrm{C}_{\mathrm{H}_{2} \mathrm{O}}$ in each intact hydropenic animal, although the renal perfusion pressure was not allowed to increase in any of these experiments (Fig. 1). The mean Uosm decreased from $616 \pm 89 \mathrm{SEM}$ to $126 \pm 13 \mathrm{mosmol} / \mathrm{kg}$ ( $P$ $<0.001$ ) with the $\mathrm{NE}$ infusion and increased to 532 mosmol $/ \mathrm{kg} \mathrm{H} \mathrm{H}_{2} \mathrm{O}(P<0.001)$ after cessation of the infusion. At the same time, the mean $\mathrm{C}_{\mathrm{H}_{2} \mathrm{O}}$ increased from $-0.44 \pm 0.1$ to $1.59 \mathrm{ml} / \mathrm{min}(P<0.001)$ with the infusion of $\mathrm{NE}$ and decreased to $-0.31 \mathrm{ml} / \mathrm{min}(P$ $<0.001)$ after cessation of the infusion. This effect of $\mathrm{NE}$ to increase renal water excretion was associated with a mean rise in arterial pressure from $121 \pm 7.8$ to $142 \pm 6.6 \mathrm{~mm} \mathrm{Hg}(P<0.005)$ which decreased to $117 \pm 8.4 \mathrm{~mm} \mathrm{Hg}(P<0.005)$ after cessation of the infusion. Although this rise in arterial pressure was primarily due to an increase in total peripheral resistance, cardiac output did increase in four of six experiments in which it was measured. This effect was, however, not statistically significant. The infusion of NE was associated with a small but significant increase in hematocrit which returned to control level after the infusion was stopped.

The diuretic effect of intravenous NE was not associated with significant alterations in renal hemodynamics or solute excretion. Mean GFR was $49.6 \pm 2.9,50.3 \pm 3.1$, and $53.5 \pm 3.2 \mathrm{ml} / \mathrm{min}$ before, during, and after the infusion of $\mathrm{NE}$, respectively, as RVR was $0.495 \pm 0.05$, $0.495 \pm 0.06$, and $0.439 \pm 0.05 \mathrm{~mm} \mathrm{Hg} \mathrm{ml} / \mathrm{min}$. Although FF was not significantly changed during the infusion $(0.331 \pm 0.01$ to $0.348 \pm 0.02)$, there was a significant fall in FF to $0.315 \pm 0.01(P<0.025)$ after cessation of the infusion. Neither sodium nor potassium excretion increased significantly during the infusion of $\mathrm{NE}$ but there was a significant increase in sodium excretion after cessation of the infusion.
Group II, effects of intravenous NE in hypophysectomized dogs receiving $80 \mu \mathrm{U} / \mathrm{kg}$ per min of vasopressin (Fig. 2, Table $I I$ ). The intravenous infusion of $\mathrm{NE}$ in the hypophysectomized dog receiving $80 \mu \mathrm{U} / \mathrm{kg}$ per min vasopressin was not associated with either a decrease in $\mathrm{U}_{\text {osm }}$ or an increase in $\mathrm{C}_{\mathrm{H}_{2} \mathrm{O}}$ (Fig. 2). The mean Uosm was $1039 \pm 117$ before, $1019 \pm 96$ during, and $1053 \pm 78$ mosmol $/ \mathrm{kg} \mathrm{H}_{2} \mathrm{O}$ after the $\mathrm{NE}$ infusion, as $\mathrm{C}_{\mathrm{H}_{2} \mathrm{O}}$ was $-0.39 \pm 0.04,-0.36 \pm 0.03$, and $-0.41 \pm 0.05$ $\mathrm{ml} / \mathrm{min}$, respectively. This absence of a diuretic effect of $\mathrm{NE}$ in these studies was observed over a wide range of control Uosm (range: 385-2232 mosmol/ $\mathrm{kg} \mathrm{H} \mathrm{H}_{2} \mathrm{O}$ ). Although intravenous $\mathrm{NE}$ failed to produce a water diuresis in these hypophysectomized dogs, the effects on systemic and renal hemodynamics were quite similar to those observed during the $\mathrm{NE}$ infusion in the intact hydropenic dog. The intravenous infusion of $\mathrm{NE}$ was not associated with a significant change in cardiac output (3.4 \pm 0.4 to $3.5 \pm 0.4$ liters $/ \mathrm{min}$ ) but cardiac output decreased significantly to $2.9 \pm 0.3$ liters $/ \mathrm{min}(P<0.02)$ after cessation of the infusion. Systemic arterial pressure increased from $111 \pm 4.7$ to $149 \pm 5.5 \mathrm{~mm} \mathrm{Hg}(P<0.001)$ during the $\mathrm{NE}$ infusion and diminished to $103 \pm 5.4 \mathrm{~mm}$ $\mathrm{Hg}$ with cessation of the infusion $(P<0.001)$. Renal perfusion pressure was kept constant at $107 \pm 4.7$ during the $\mathrm{NE}$ infusion but diminished to $98 \pm 3.3 \mathrm{~mm} \mathrm{Hg}(P<$ 0.05) after the infusion was stopped. As in the intact animals, the NE infusion was associated with a modest but consistent increase in hematocrit. GFR and RVR were not significantly altered by the $\mathrm{NE}$ infusion but a reversible increase in $\mathrm{FF}$ was observed. The $\mathrm{NE}$ infusion was associated with a small but significant decrease in both sodium and potassium excretion.

Group III, effects of intravenous NE in hypophysectomized dogs receiving $20-40 \mu \mathrm{U} / \mathrm{kg}$ per min of vasopressin (Fig. 3, Table III). The intravenous infusion of $\mathrm{NE}$ in the hypophysectomized dogs receiving 20-40

Norepinephrine and Renal Water Excretion 
TABLE II

Effect of Norepinephrine Infusion on Systemic and Renal Hemodynamics and

\begin{tabular}{|c|c|c|c|c|c|c|c|c|c|c|c|c|c|}
\hline & \multicolumn{3}{|c|}{ Cardiac output } & \multicolumn{3}{|c|}{$\begin{array}{c}\text { Systemic } \\
\text { arterial pressure }\end{array}$} & \multicolumn{3}{|c|}{$\begin{array}{c}\text { Renal } \\
\text { perfusion pressure }\end{array}$} & \multicolumn{3}{|c|}{$\begin{array}{c}\text { Arterial } \\
\text { hematocrit volume }\end{array}$} & \multirow{2}{*}{$\frac{\text { GFR }}{\begin{array}{c}\text { Pre- } \\
\text { control }\end{array}}$} \\
\hline & $\begin{array}{c}\text { Pre- } \\
\text { control }\end{array}$ & $\mathrm{NE}$ & $\begin{array}{l}\text { Post- } \\
\text { control }\end{array}$ & $\begin{array}{l}\text { Pre- } \\
\text { control }\end{array}$ & $\mathrm{NE}$ & $\begin{array}{l}\text { Post- } \\
\text { control }\end{array}$ & $\begin{array}{l}\text { Pre- } \\
\text { control }\end{array}$ & $\mathrm{NE}$ & $\begin{array}{l}\text { Post- } \\
\text { control }\end{array}$ & $\begin{array}{l}\text { Pre- } \\
\text { control }\end{array}$ & $\mathrm{NE}$ & $\begin{array}{l}\text { Post- } \\
\text { control }\end{array}$ & \\
\hline & \multicolumn{3}{|c|}{ liters/min } & \multicolumn{3}{|c|}{$m m \mathrm{Hg}$} & \multicolumn{3}{|c|}{$m m \mathrm{Hg}$} & \multicolumn{3}{|c|}{$\%$} & $\mathrm{ml} / \mathrm{min}$ \\
\hline Mean & 3.4 & 3.5 & 2.9 & 111 & 149 & 103 & 107 & 107 & 98 & 47.2 & 52.0 & 48.9 & 40.7 \\
\hline$\pm \mathrm{SE}$ & \pm 0.4 & \pm 0.4 & \pm 0.3 & \pm 4.7 & \pm 5.5 & \pm 5.4 & \pm 5.1 & \pm 4.7 & \pm 3.3 & \pm 1.8 & \pm 1.9 & \pm 2.2 & \pm 17.0 \\
\hline$P$ value & $\mathrm{N}$ & $S<0$ & & $<0$. & $01<$ & 0.001 & & $<0$ & & $<0 . \mathrm{C}$ & $05<0$ & 0.005 & NS \\
\hline
\end{tabular}

* The results are the mean values from 10 experiments; the values for renal hemodynamic and electrolyte excretion are expressed per kidney.

See Table I for abbreviations.

$\mu \mathrm{U} / \mathrm{kg}$ per min of vasopressin was also not associated with either a significant decrease in Uosm or increase in $\mathrm{C}_{\mathrm{H}_{2} \mathrm{O}}$ (Fig. 3). In these animals the mean $\mathrm{U}_{\mathrm{osm}}$ and $\mathrm{C}_{\mathrm{H}_{2} \mathrm{O}}$ after the acute hypophysectomy but before the infusion of vasopressin was $86 \pm 14$ mosmol and $2.05 \pm 0.41$ $\mathrm{ml} / \mathrm{min}$, respectively. During the vasopressin infusion the mean $\mathrm{U}_{\text {osm }}$ was $238 \pm 17$ mosmol before, $287 \pm 27$ mosmol during, and $342 \pm 35$ mosmol after the NE infusion. The small rise in $U_{\text {os } m}$ from 238 to 287 mosmol was significant at a $P$ value of $<0.02$. During the same period of time the $\mathrm{C}_{\mathrm{H}_{2} \mathrm{O}}$ was $0.162 \pm 0.16 \mathrm{ml} / \mathrm{min}$ before, $0.059 \pm 0.07 \mathrm{ml} / \mathrm{min}$ during, and $0.004 \pm 0.07 \mathrm{ml} / \mathrm{min}$ after the NE infusion. The effects of the intravenous norepinephrine on systemic and renal hemodynamics were similar to those observed in the group I and II studies. There was no significant change in cardiac output but systemic arterial pressure increased from 115 \pm 8.5 to $152 \pm 6.0 \mathrm{~mm} \mathrm{Hg}(P<0.001)$ during the $\mathrm{NE}$ infusion and decreased to $111 \pm 7.3 \mathrm{~mm} \mathrm{Hg}(P<0.001)$ after cessation of the $\mathrm{NE}$ infusion. The renal perfusion pressure was kept constant throughout the experiments. A significant increase in hematocrit occurred during the $\mathrm{NE}$ infusion but the hematocrit did not decrease after cessation of the infusion. A significant increase in GFR and FF occurred during the $\mathrm{NE}$ infusion and was reversible after discontinuance of the infusion. There were no significant alterations in sodium and potassium excretion.

Group IV, effects of intrarenal NE in hypophysectomized dogs receiving 20-30 $\mathrm{\mu U} / \mathrm{kg}$ per min of vasopressin (Table $I V)$. The dose of NE infused directly into the renal artery was estimated to deliver an amount of $\mathrm{NE}$ to the renal circulation which was equal to or greater than the amount reaching the kidney during the
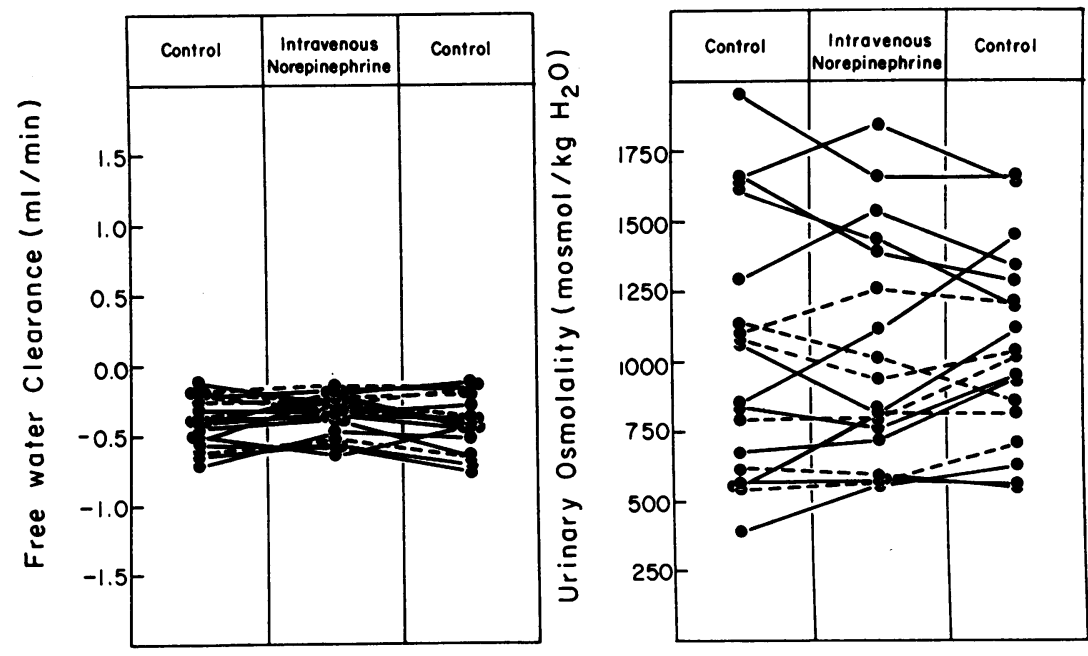

FIGURE 2 Absence of effect of intravenous norepinephrine on free water clearance (left) and urinary osmolality (right) in hypophysectomized dogs receiving $80 \mu \mathrm{U} / \mathrm{kg}$ per min of vasopressin. Each point is the mean of three to five collections. Solid lines denote results in innervated kidneys and dotted lines in denervated kidneys. 
Electrolyte Excretion in Hypophysectomized Dogs Receiving Vasopressin*

\begin{tabular}{|c|c|c|c|c|c|c|c|c|c|c|c|c|c|}
\hline \multicolumn{2}{|c|}{ GFR } & \multicolumn{3}{|c|}{ RVR } & \multicolumn{3}{|c|}{$\mathrm{FF}$} & \multicolumn{3}{|c|}{$\begin{array}{c}\text { Urinary } \\
\text { sodium excretion }\end{array}$} & \multicolumn{3}{|c|}{$\begin{array}{c}\text { Urinary } \\
\text { potassium excretion }\end{array}$} \\
\hline $\mathrm{NE}$ & $\begin{array}{l}\text { Post- } \\
\text { control }\end{array}$ & $\begin{array}{c}\text { Pre- } \\
\text { control }\end{array}$ & $\mathrm{NE}$ & $\begin{array}{l}\text { Post- } \\
\text { control }\end{array}$ & $\begin{array}{c}\text { Pre- } \\
\text { control }\end{array}$ & $\mathrm{NE}$ & $\begin{array}{l}\text { Post- } \\
\text { control }\end{array}$ & $\begin{array}{l}\text { Pre- } \\
\text { control }\end{array}$ & $\mathrm{NE}$ & $\begin{array}{l}\text { Post- } \\
\text { control }\end{array}$ & $\begin{array}{l}\text { Pre- } \\
\text { control }\end{array}$ & $\mathrm{NE}$ & $\begin{array}{l}\text { Post- } \\
\text { control }\end{array}$ \\
\hline \multicolumn{2}{|c|}{$\mathrm{ml} / \mathrm{min}$} & \multicolumn{3}{|c|}{$m m \mathrm{Hg}(\mathrm{ml} / \mathrm{min})$} & & & & \multicolumn{3}{|c|}{$\mu e q / \min$} & \multicolumn{3}{|c|}{$\mu e q / \min$} \\
\hline $\begin{array}{r}41.5 \\
\pm 4.9\end{array}$ & $\begin{array}{r}42.6 \\
\pm 8.2\end{array}$ & $\begin{array}{l}\quad 0.464 \\
\pm 0.03\end{array}$ & $\begin{aligned} & 0.496 \\
\pm & 0.02\end{aligned}$ & $\begin{array}{ll} & 0.453 \\
\pm & 0.03\end{array}$ & $\begin{array}{l}\quad 0.323 \\
\pm 0.01\end{array}$ & $\begin{aligned} & 0.394 \\
\pm & 0.01\end{aligned}$ & $\begin{aligned} & 0.361 \\
\pm & 0.01\end{aligned}$ & $\begin{array}{c}4 \\
\pm 1.3\end{array}$ & $\begin{array}{c}2 \\
\pm 0.5\end{array}$ & $\begin{array}{c}5 \\
\pm 1.4\end{array}$ & $\begin{array}{l}23 \\
\pm 2.5\end{array}$ & $\begin{array}{l}18 \\
\pm 2.0\end{array}$ & $\begin{array}{l}27 \\
\pm 3.8\end{array}$ \\
\hline NS & & & NS NS & & $<0$ & $001<0$ & .001 & $<0$ & $05<$ & 0.05 & $<0$. & $2<$ & 001 \\
\hline
\end{tabular}

group I studies. In the group I studies with a mean cardiac output of $4200 \mathrm{ml} / \mathrm{min}$ and a mean renal blood flow per kidney of $234 \mathrm{ml} / \mathrm{min}$, even in the absence of metabolism a maximum of $\frac{1}{16}$ th of the active drug would have reached the renal circulation. In the group IV intrarenal experiments approximately ${ }_{1}^{1}$ th of the intravenous dose of $\mathrm{NE}$ was infused into the renal artery in an effort to demonstrate an intrarenal effect of $\mathrm{NE}$ on renal water excretion. The water diuresis observed in the group I experiments did not occur in these group IV experiments as $\mathrm{C}_{\mathrm{H}_{2} \mathrm{O}}$ was $-0.433 \pm 0.10$ $\mathrm{ml} / \mathrm{min}$ before, $-0.432 \pm 0.12 \mathrm{ml} / \mathrm{min}$ during, and $-0.426 \pm 0.08 \mathrm{ml} / \mathrm{min}$ after the intrarenal $\mathrm{NE}$ infusion.
The Uosm was $812 \pm 163,668 \pm 108$, and $781 \pm 155$ mos$\mathrm{mol} / \mathrm{kg} \mathrm{H} \mathrm{H}_{2} \mathrm{O}$ during the same periods. None of these changes reached a level of significance. In four kidneys a diminution in $\mathrm{U}_{\mathrm{osm}}$ occurred during the $\mathrm{NE}$ infusion and in the remaining four kidneys the Uosm either was unchanged or increased during the $\mathrm{NE}$ infusion. Changes in GFR and RVR did not correlate with these changes in Uosm in these eight kidneys.

\section{DISCUSSION}

There is considerable evidence that the effect of intravenous norepinephrine to increase the renal excretion of solute-free water is related to the alpha adrenergic-
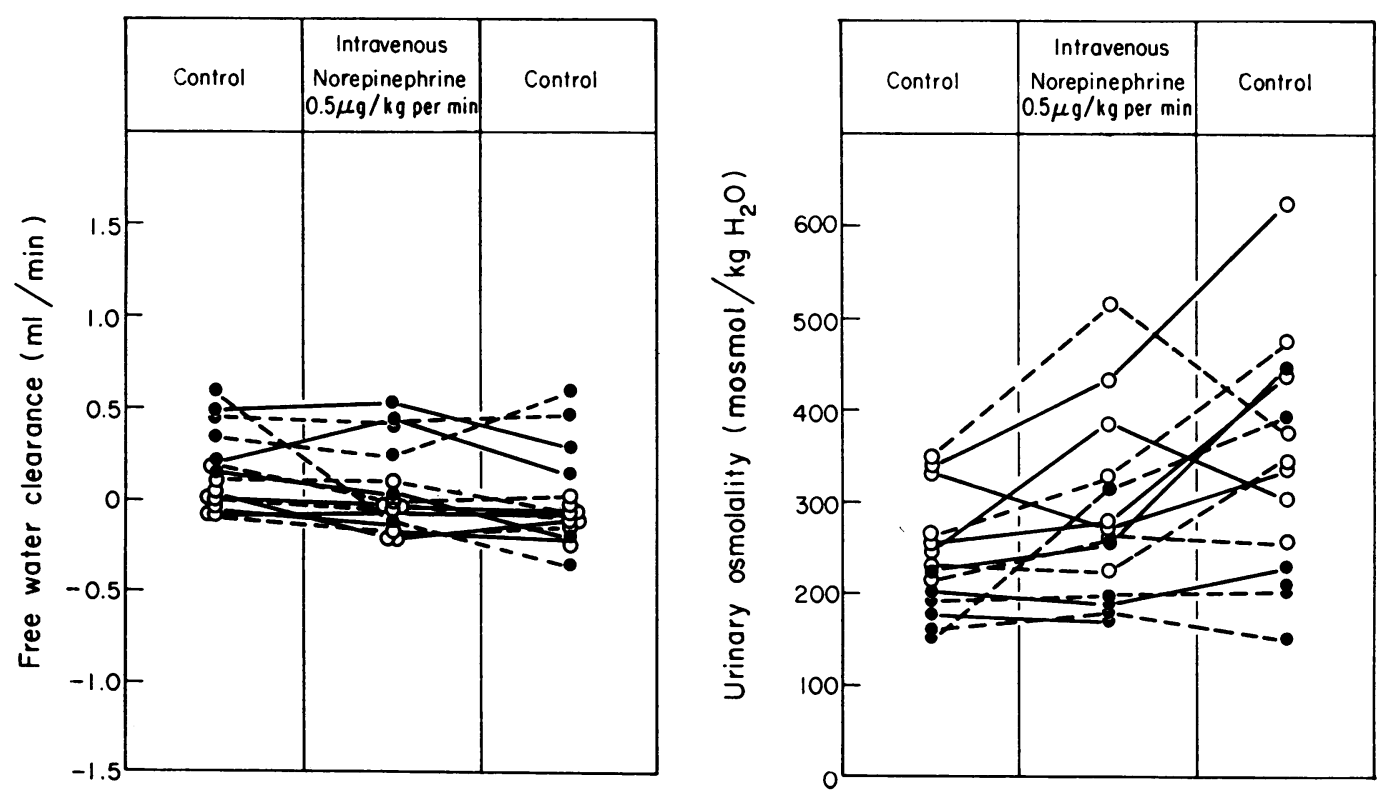

FIGURE 3 Absence of effect of intravenous norepinephrine on free water clearance (left) and urinary osmolality (right) in hypophysectomized dogs receiving $20-40 \mu \mathrm{U} / \mathrm{kg}$ per min of vasopressin. Each point is the mean of three to five collections. Solid lines denote results in innervated kidneys and dotted lines in denervated kidneys. The open circles represent experiments in which $40 \mu \mathrm{U} / \mathrm{kg}$ per min of vasopressin was infused and the closed circles represent experiments in which $20 \mu \mathrm{U} / \mathrm{kg}$ per min of vasopressin was infused. 
TABLE III

The Effect of Intravenous Norepinephrine on Systemic in Hypophysectomized Dogs

\begin{tabular}{|c|c|c|c|c|c|c|c|c|c|c|c|c|c|}
\hline & \multicolumn{3}{|c|}{ Cardiac output } & \multicolumn{3}{|c|}{$\begin{array}{c}\text { Systemic } \\
\text { arterial pressure }\end{array}$} & \multicolumn{3}{|c|}{$\begin{array}{c}\text { Renal } \\
\text { perfusion pressure }\end{array}$} & \multicolumn{3}{|c|}{$\begin{array}{c}\text { Arterial } \\
\text { hematocrit volume }\end{array}$} & \multirow{2}{*}{$\frac{\text { GFR }}{\begin{array}{c}\text { Pre- } \\
\text { control }\end{array}}$} \\
\hline & $\begin{array}{l}\text { Pre- } \\
\text { control }\end{array}$ & $\mathrm{NE}$ & $\begin{array}{l}\text { Post- } \\
\text { control }\end{array}$ & $\begin{array}{l}\text { Pre- } \\
\text { control }\end{array}$ & $\mathrm{NE}$ & $\begin{array}{l}\text { Post- } \\
\text { control }\end{array}$ & $\begin{array}{c}\text { Pre- } \\
\text { control }\end{array}$ & $\mathrm{NE}$ & $\begin{array}{l}\text { Post- } \\
\text { control }\end{array}$ & $\begin{array}{c}\text { Pre- } \\
\text { control }\end{array}$ & $\mathrm{NE}$ & $\begin{array}{l}\text { Post- } \\
\text { control }\end{array}$ & \\
\hline & \multicolumn{3}{|c|}{ liters/min } & \multicolumn{3}{|c|}{$m m \mathrm{Hg}$} & \multicolumn{3}{|c|}{$m m \mathrm{Hg}$} & \multicolumn{3}{|c|}{$\%$} & $\operatorname{ml} / \min$ \\
\hline $\begin{array}{l}\text { Mean } \\
\pm S E\end{array}$ & $\begin{array}{r}3.1 \\
\pm 0.4\end{array}$ & $\begin{array}{r}2.9 \\
\pm 0.1\end{array}$ & $\begin{array}{r}3.2 \\
\pm 0.4\end{array}$ & $\begin{array}{l}115 \\
\pm 8.5\end{array}$ & $\begin{array}{l}152 \\
\pm 6.0\end{array}$ & $\begin{array}{l}111 \\
\pm 7.3\end{array}$ & $\begin{array}{l}109 \\
\pm 4.6\end{array}$ & $\begin{array}{l}109 \\
\pm 6.2\end{array}$ & $\begin{array}{l}104 \\
\pm 4.1\end{array}$ & $\begin{array}{r}41.4 \\
\pm 1.2\end{array}$ & $\begin{array}{r}43.6 \\
\pm 1.1\end{array}$ & $\begin{array}{r}42.1 \\
\pm 0.4\end{array}$ & $\begin{array}{r}41.7 \\
\pm 2.8\end{array}$ \\
\hline$P$ value & \multicolumn{3}{|c|}{ NS } & \multicolumn{3}{|c|}{$<0.001<0.001$} & \multicolumn{3}{|c|}{ NS NS } & \multicolumn{3}{|c|}{$<0.05 \quad \mathrm{NS}$} & $<0.02$ \\
\hline
\end{tabular}

* The results are the mean values from seven experiments; the values for renal hemodynamic and electrolyte excretion are expressed per kidney.

See Table I for abbreviations.

stimulating properties of the hormone. Although norepinephrine stimulates both alpha and beta adrenergic receptors, the diuretic effect of norepinephrine has been found to be abolished by alpha but not beta adrenergic blockade $(4,5)$. Moreover, beta adrenergic stimulation with intravenous isoproterenol is associated with an antidiuretic rather than a diuretic effect (17). The mechanism whereby alpha adrenergic stimulation increases renal water excretion, however, is not clearly understood. The increase in systemic and renal arterial pressure which occurs during the intravenous infusion of norepinephrine could account for this diuretic effect (13-14). However, in present experiments the renal perfusion pressure was kept constant, and yet the intravenous infusion of norepinephrine was consistently associated with an increase in renal water excretion. The enhanced water excretion during the intravenous norepinephrine infusion was also not associated with either a significant increase in glomerular filtration rate or solute excretion rate and was not abolished by renal denervation.

These findings, therefore, suggested that the effect of norepinephrine to increase solute-free water excretion might be mediated by either an antagonism of the action of vasopressin or by a suppression of release of endogenous vasopressin. The latter mechanism was possible since the dose of intravenous norepinephrine which was used in the present and previous studies is associated with an increase in total peripheral resistance and in systemic arterial pressure (1-5). Although, in the present experiments renal arterial pressure was kept constant by adjustment of a suprarenal aortic clamp the systemic arterial pressure above the clamp, and in particular in the cerebral circulation, was increased. This increase in arterial pressure, or some consequence thereof, could have diminished the release of vasopressin and thereby accounted for the observed diuretic effect. This possibility was examined by investigating whether intravenous norepinephrine is associated with

TABLE IV

The Effect of Renal Arterial Infusion of Norepinephrine on Hypophysectomized Dogs.

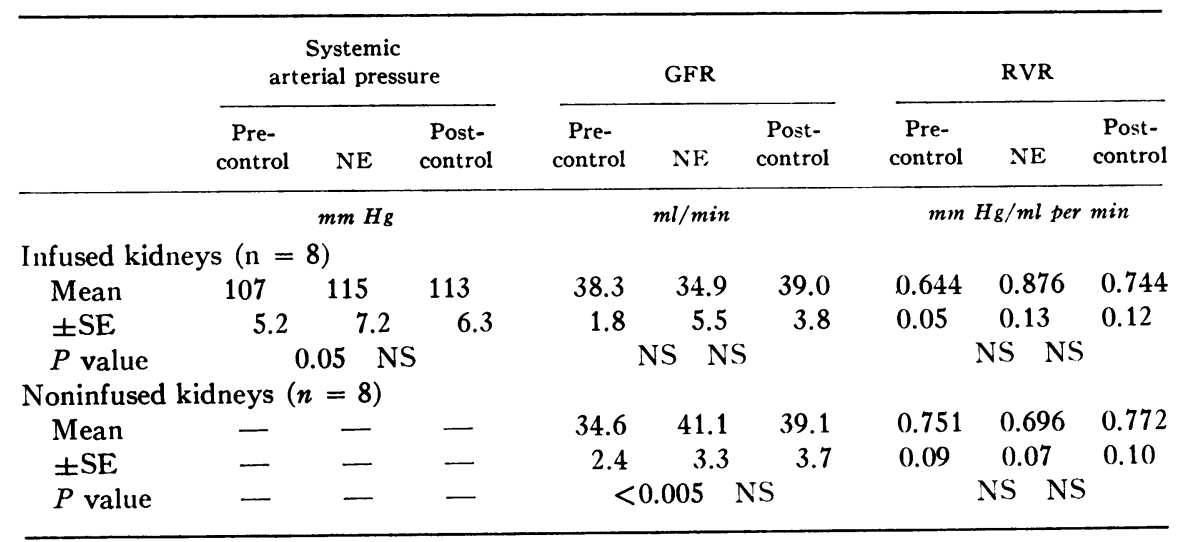


and Renal Hemodynamics and Electrolyte Excretion* Receiving Low Doses of Vasopressin

\begin{tabular}{|c|c|c|c|c|c|c|c|c|c|c|c|c|c|}
\hline \multicolumn{2}{|c|}{ GFR } & \multicolumn{3}{|c|}{ RVR } & \multicolumn{3}{|c|}{$\mathrm{FF}$} & \multicolumn{3}{|c|}{$\begin{array}{c}\text { Urinary } \\
\text { sodium excretion }\end{array}$} & \multicolumn{3}{|c|}{$\begin{array}{c}\text { Urinary } \\
\text { potassium excretion }\end{array}$} \\
\hline $\mathrm{NE}$ & $\begin{array}{l}\text { Post- } \\
\text { control }\end{array}$ & $\begin{array}{l}\text { Pre- } \\
\text { control }\end{array}$ & $\mathrm{NE}$ & $\begin{array}{l}\text { Post- } \\
\text { control }\end{array}$ & $\begin{array}{l}\text { Pre- } \\
\text { control }\end{array}$ & $\mathrm{NE}$ & $\begin{array}{l}\text { Post- } \\
\text { control }\end{array}$ & $\begin{array}{l}\text { Pre- } \\
\text { control }\end{array}$ & $\mathrm{NE}$ & $\begin{array}{l}\text { Post- } \\
\text { control }\end{array}$ & $\begin{array}{l}\text { Pre- } \\
\text { control }\end{array}$ & $\mathrm{NE}$ & $\begin{array}{l}\text { Post- } \\
\text { contro }\end{array}$ \\
\hline \multicolumn{2}{|c|}{$\mathrm{ml} / \mathrm{min}$} & \multicolumn{3}{|c|}{$m m H g(m l / m i n)$} & & & & \multicolumn{3}{|c|}{$\mu e q / m i n$} & \multicolumn{3}{|c|}{$\mu e q / \min$} \\
\hline $\begin{array}{r}45.1 \\
\pm 2.5\end{array}$ & $\begin{array}{r}40.3 \\
\pm 2.9\end{array}$ & $\begin{aligned} & 0.586 \\
\pm & 0.04\end{aligned}$ & $\begin{aligned} & 0.600 \\
\pm & 0.03\end{aligned}$ & $\begin{aligned} & 0.563 \\
\pm & 0.03\end{aligned}$ & $\begin{aligned} & 0.365 \\
\pm & 0.02\end{aligned}$ & $\begin{aligned} & 0.428 \\
\pm & 0.02\end{aligned}$ & $\begin{aligned} & 0.358 \\
\pm & 0.02\end{aligned}$ & $\begin{array}{c}8 \\
\pm 3.0\end{array}$ & $\begin{array}{l}12 \\
\pm 5.9\end{array}$ & $\begin{array}{l}23 \\
\pm 7.9\end{array}$ & $\begin{array}{l}23 \\
\pm 3.1\end{array}$ & $\begin{array}{l}24 \\
\pm 2.7\end{array}$ & $\begin{array}{l}27 \\
\pm 4.1\end{array}$ \\
\hline \multicolumn{2}{|c|}{$<0.02$} & \multicolumn{3}{|c|}{ NS NS } & \multicolumn{3}{|c|}{$<0.001<0.001$} & \multicolumn{3}{|c|}{ NS NS } & \multicolumn{3}{|c|}{ NS NS } \\
\hline
\end{tabular}

a similar water diuresis when infused into animals whose pituitary source of vasopressin had been removed. In these acutely hypophysectomized dogs receiving glucocorticoid replacement ${ }^{2}$ and a constant infusion of vasopressin the intravenous infusion of norepinephrine failed to elicit a water diuresis. The result thus suggested that suppression of vasopressin release was the primary pathway whereby norepinephrine increases the renal excretion of solute-free water.

The dose of vasopressin $(80 \mu \mathrm{g} / \mathrm{kg}$ per $\mathrm{min})$ used in the group II studies in hypophysectomized dogs was chosen by titrating the infusion of exogenous vaso-

${ }^{2}$ Recent preliminary data by Levi, Massry, and Kleeman (18) has emphasized the necessity of glucocorticoid hormone replacement to demonstrate the diuretic effect of norepinephrine in adrenalectomized dogs. In this regard, in the present study dexamethasone was administered to the hypophysectomized animals both intravenously and intramuscularly in a dose twofold that previously demonstrated to be adequate glucocorticoid replacement for adrenalectomized dogs (19). pressin to a level which was associated with a range of urinary osmolalities similar to those found in the intact hydropenic animals (group I). In only 4 of the 18 kidneys in the group II hypophysectomized dogs were the urinary osmolalities above the range observed in the intact animals in group I. The dose of vasopressin used in these group II studies also was considerably less than the dose of vasopressin reported to produce a maximal antidiuresis in the anesthetized dog (20). Even so, if the effect of norepinephrine on renal water excretion is in part due to a competitive inhibition of the action of vasopressin, the possibility existed that the level of vasopressin in these group II studies may have been sufficiently high to have obscured this competitive effect of norepinephrine. Such a possibility has been previously suggested to explain the finding that the effect of norepinephrine on renal water excretion in humans was demonstrable only in the presence of submaximal doses of vasopressin (3). Suppression of endogenous vasopressin and an increase in renal perfusion

Systemic and Renal Hemodynamics and Water Excretion in Receiving Vasopressin

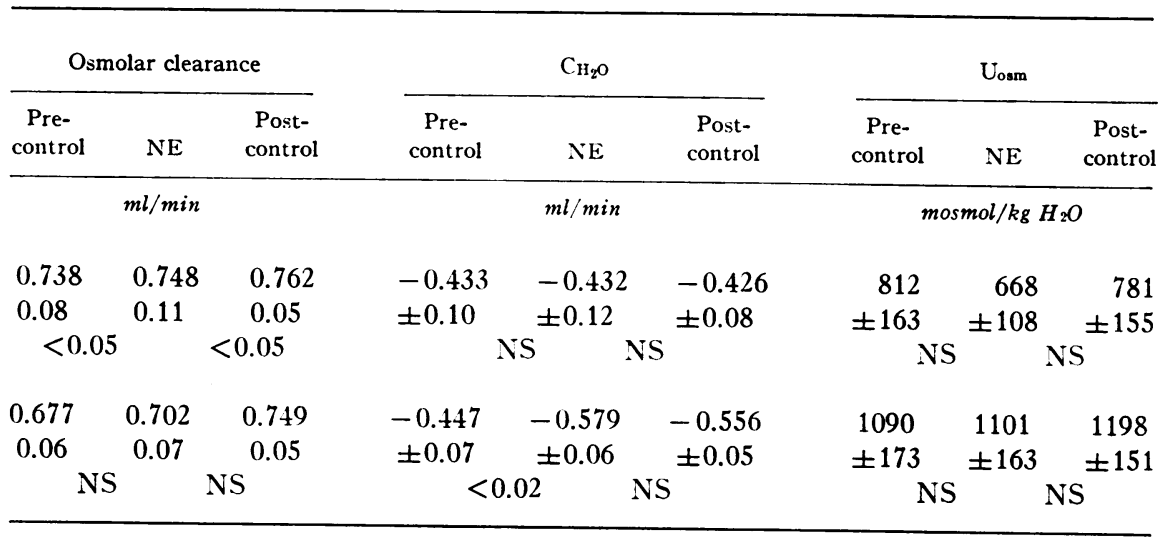


pressure, however, were not excluded as factors in the observed water diuresis in this previous study (3). We, therefore, undertook studies to examine whether intravenous norepinephrine was associated with a water diuresis in hypophysectomized dogs receiving low doses of vasopressin $(20-40 \mu \mathrm{g} / \mathrm{kg}$ per $\mathrm{min})$. This dose of vasopressin is in the same range as that used in a previous study in the $\operatorname{dog}$ in which intravenous norepinephrine was demonstrated to be associated with a water diuresis (5). In this previous investigation, however, renal perfusion pressure was allowed to increase during the intravenous infusion of norepinephrine. Maximal suppression of endogenous vasopressin also may not have been present before the norepinephrine infusion since the control urinary osmolalities were in a range compatible with the presence of some endogenous vasopressin (150-170 mosmol $/ \mathrm{kg}$ ) (5). After acute hypophysectomy in the present group III animals the mean urinary osmolality was $87 \mathrm{mosmol} / \mathrm{kg}$ before starting the administration of the low dose of vasopressin. After the vasopressin administration the mean urinary osmolality of $238 \mathrm{mosmol} / \mathrm{kg}$ was significantly below the mean urinary osmolality in either the intact dogs (group I) or the hypophysectomized dogs receiving higher doses of exogenous vasopressin (group II). In these group III studies, as in the group II studies, the intravenous infusion of norepinephrine was not associated with a significant alteration in urinary osmolality or free water clearance (Fig. 3). These results thus further support the conclusion that suppression of endogenous vasopressin is the primary mechanism whereby the intravenous infusion of norepinephrine is associated with a water diuresis.

This finding that alpha adrenergic stimulation may suppress vasopressin release does not exclude an additional competive effect of norepinephrine on the action of vasopressin particularly with larger doses of the catecholamine as may be used in in vitro studies. It does, however, seem likely that the previous effects of norepinephrine on renal water excretion, in which the doses of norepinephrine per body weight were similar to that used in the present study, were primarily related to suppression of endogenous vasopressin and/or increases in renal perfusion pressure (1-5). In the present group IV studies a dose of norepinephrine was infused into the renal artery in an amount estimated to exceed that reaching the kidney during the intravenous studies, and yet in a dose not causing a degree of renal vasoconstriction that would obscure any effect of norepinephrine to antagonize the action of vasopressin on the water permeability of the tubular epithelium. In these studies a small diminution in mean urinary osmolality was observed in the infused kidney but this effect was neither consistent nor statistically significant. Thus, a modest inhibition of the action of vasopressin by norepinephrine cannot be excluded but the conclusive demonstration of such an effect may not be possible in in vivo experiments.

There are several potential mechanisms whereby alpha adrenergic stimulation with intravenous norepinephrine may be associated with a suppression of endogenous vasopressin. Some authors (21) have suggested that catecholamines may directly suppress the release of vasopressin. While the results of recent investigations suggest that the effect of isoproterenol (17) and prostaglandin (22) on vasopressin release is mediated indirectly as a consequence of alterations in systemic hemodynamics, the present results do not exclude a direct central effect of norepinephrine on vasopressin release. Alternatively, however, the increase in systemic arterial pressure which occurred during the intravenous infusion of norepinephrine could have caused a suppression of vasopressin release or initiated a reflex which in turn led to a diminution in vasopressin release. In regards to the latter possibility, an increase in systemic arterial pressure might be expected to increase parasympathetic afferent vagal tone and thereby suppress vasopressin release. In support of this possibility are the results of recent experiments using similar techniques which demonstrated that an interruption of parasympathetic afferent, but not efferent, pathways is associated with increased vasopressin release (23). Cardiovascular effects other than changes in arterial pressure, such as alterations in venous tone or transmural atrial pressure, might also initiate such a reflex involving changes in parasympathetic afferent tone and vasopressin release. Although intravenous infusion of catecholamines, such as norepinephrine and isoproterenol, are known to increase renin secretion $(24,25)$, a role of angiotensin in the diuretic effect of norepinephrine seems unlikely since existing evidence suggests that angiotensin stimulates rather than suppresses vasopressin release (26). Taken together then with other recently published results from our laboratory $(17,22$, 23) changes in systemic hemodynamics and autonomic neural tone seem the most likely pathway whereby norepinephrine suppresses the endogenous release of vasopressin. This same mechanism may also provide the pathway whereby changes in emotions, volume status, or drug administration exert an effect on renal water excretion in the absence of changes plasma osmolality. Further studies will, however, be necessary to confirm this tentative hypothesis.

\section{ACKNOWLEDGMENTS}

The authors are indebted to Miss Lisbeth Streiff and Vicki Neel for invaluable technical assistance and to Mrs. Vicki Wagner for secretarial assistance. 
This work was supported by grants HE 13319-01 and AM 12753 from the National Institutes of Health, and by NGR 0f-025-007 from the National Aeronautics and Space Administration and the Bay Area Heart Association.

\section{REFERENCES}

1. Smythe, C. McC., J. F. Nickel, and S. E. Bradley. 1952. The effect of epinephrine (USP), $l$-epinephrine, and $l$ norepinephrine on glomerular filtration rate, renal plasma flow, and the urinary excretion of sodium, potassium, and water in normal man. J. Clin. Invest. 31: 499.

2. Baldwin, D. S., E. A. Gombos, and H. Chasis. 1963. Changes in sodium and water excretion induced by epinephrine and $l$-norepinephrine in normotensive and hypertensive subjects. J. Lab. Clin. Med. 61: 832 .

3. Fisher, D. A. 1968. Norepinephrine inhibition of vasopressin antidiuresis. J. Clin. Invest. $47: 540$.

4. Liberman, B., L. A. Klein, and C. R. Kleeman. 1970. Effect of adrenergic blocking agents on the vasopressin inhibiting action of norepinephrine. Proc. Soc. Exp. Biol. Med. 133: 131 .

5. Klein, L. A., B. Liberman, M. Laks, and C. R. Kleeman. 1971. Interrelated effects of antidiuretic hormone and adrenergic drugs on water metabolism. Am. J. Physiol. 221 : 1657.

6. Orloff, J., and J. Handler. 1967. The role of adenosine $3^{\prime}, 5^{\prime}$-phosphate in the action of antidiuretic hormone. Am. J. Med. $42: 757$.

7. Sutherland, E. W., and G. A. Robison. 1967. The role of cyclic $3^{\prime}, 5^{\prime}$-adenosine monophosphate synthesis in tissues. Biochem. Biophys. Res. Commun. 28: 797.

8. Chase, L. R., and G. D. Aurbach. 1968. Renal adenyl cyclase: anatomically separate sites for parathyroid hormone and vasopressin. Science (Wash. D. C.). 159: 545.

9. Porte, D., Jr. 1967. A receptor mechanism for the inhibition of insulin release by epinephrine in man. J. Clin. Invest. 46: 86 .

10. Turtle, J. R., and D. M. Kipnis. 1967. An adrenergic receptor mechanism for the control of cyclic $3^{\prime}, 5^{\prime}$-adenosine monophosphate synthesis in tissues. Biochem. Biophys. Res. Commun. 28: 797.

11. Strauch, B. S., and R. G. Langdon. 1969. Tyramine, catechol amines, and the action of vasopressin stimulation of water efflux in toad bladders. Arch. Biochem. Biophys. 129 : 277.

12. Handler, J. S., R. Bensinger, and J. Orloff. 1968. Effect of adrenergic agents on toad bladder response to ADH, 3',5'-AMP, and theophylline. Am. J. Physiol. 215: 1024.
13. Selkurt, E. E., I. Womack, and W. N. Dailey. 1965. Mechanism of natriuresis and diuresis during elevated renal arterial pressure. Am. J. Physiol. 209: 95.

14. Thurau, K., and P. Deetjen. 1962. Die Diurese bei arteriellen Drucksteigerungen: Bedeutung der Hämodynamik des Nierenmarkes für die Harnkonzentrierung. Pflïegers Arch. 274: 567.

15. Schrier, R. W., and M. H. Humphreys. 1971. Factors involved in the antinatriuretic effects of acute constriction of the thoracic and abdominal inferior vena cava. Circ. Res. 29: 479.

16. Schrier, R. W., and L. E. Earley. 1970. Effects of hematocrit on renal hemodynamics and sodium excretion in hydropenic and volume-expanded dogs. J. Clin. Invest. 49 : 1656

17. Schrier, R. W., R. Lieberman, and R. C. Ufferman. 1972. Mechanism of antidiuretic effect of beta adrenergic stimulation. J. Clin. Invest. $51: 97$.

18. Levi, J., S. G. Massry, and C. R. Kleeman. 1972. The requirement of cortisol $(\mathrm{CpF})$ for the inhibitory effect of norepinephrine (NE) on the anti-diuretic action of vasopressin (ADH). Clin. Res. 20: 200. (Abstr.)

19. Ufferman, R. C., and R. W. Schrier. 1972. Importance of sodium intake and mineralocorticoid hormone in the impaired water excretion in adrenal insufficiency. $J$. Clin. Invest. 51: 1639.

20. Mason, J. M., and J. R. Ledsome. 1971. The effects of changes in the rate of infusion of vasopressin in anesthetized dogs. Can. J. Physiol. Pharmacol. 49: 933.

21. Abrahams, V. C., and M. Pickford. 1956. Observations on a central antagonism between adrenaline and acetylcholine. J. Physiol. (Lond.). 131: 712.

22. Berl, T., and R. W. Schrier. 1973. Mechanism of effect of prostaglandin $E_{1}$ on renal water excretion. J. Clin. Invest. 52: 463.

23. Schrier, R. W., and T. Berl. 1972. Mechanism of the antidiuretic effect associated with interruption of parasympathetic pathways. J. Clin. Invest. 51: 2613.

24. Vander, A. J. 1965. Effect of catecholamines and the renal nerves on renin secretion in anesthetized dogs. Am. J. Physiol. 209: 659.

25. Reid, I. A., R. W. Schrier, and L. E. Earley. 1972. An effect of extrarenal beta adrenergic stimulation on the release of renin. J. Clin. Invest. 51: 1861.

26. Bonjour, J. P., and R. L. Malvin. 1970. Stimulation of $\mathrm{ADH}$ release by the renin-angiotensin system. Am. J. Physiol. 218: 1555. 